\title{
Adaption of Wheat Genotypes to Drought Stress
}

\author{
M. Alsalimiya ${ }^{1}$, G. De Luigi ${ }^{2}$, E. Abu-Rabada ${ }^{1}$, H. Ayyad ${ }^{1}$, R. Basheer-Salimia ${ }^{3 *}$ \\ ${ }^{1}$ Land Research Center (LRC), Palestine; \\ ${ }^{2}$ Centro Regionale di Intervento per la Cooperazione (CRIC), Italy, and \\ ${ }^{*}$ Department of Plant Production and Protection, Faculty of Agriculture, Hebron University, Palestine \\ *Correspondence author's email: rezqbasheer@hebron.edu
}

\begin{abstract}
Drought can serve to restrict the growth and development of wheat. The current research was conducted to screen for drought-tolerant wheat genotypes through phenotypic markers, including growth indicators and yield. We used a Randomized Complete Block (RCB) design with three replicate sites (about $333 \mathrm{~m}^{2}$ area per replicate). Six wheat genotypes which are frequently grown under rain-fed conditions at the southern highland of West-Bank, Palestine were evaluated for specific phenotypes including stem length, spike with awns length, awns length, number of tillers, total grain, total hay, and mass of seeds (per 100).

The results showed significant variations among the six wheat genotypes for most of the measured parameters. Yellow-Hetia genotype showed the highest stem length, spike with awns length, awns length, weight of 100 seeds, and yield (grain plus hay). However, the remaining genotypes presented almost similar production ranging from 475-488 $\mathrm{kg} /$ dunum. In contrary, Nab-El-Jamal genotype exhibited the lowest grain production and Um-ElRabee' genotype revealed the minimum hay production. Based on our data, Yellow-Hetia could be a promising cultivar for future breeding programs, especially those involving drought tolerance.
\end{abstract}

Keywords - Wheat genotypes, drought stress, adaptation.

\section{INTRODUCTION}

Cereal crops have supplied the means for sustaining human life as direct human food sources as well as indirect sources through livestock and poultry feed. They provide around three-quarters of human caloric intake and are grown on more than two-third of the arable land area (Ahmad et al., 1989). FAO's forecast for global cereal production in 2017 is about 2627 million tonnes comparing with 2534 million tonnes in last year's production (FAO, 2016).

Wheat (Triticum aestivum L., the most important cereal crop)is currently forecast at 754.8 million tonnes for $2017 / 2018$ at $1 \%$ lower than the previous year's production (FAO, 2017).This crop is considered as the most widely cultivated plant, as well as the first important and strategic crop for the majority of the world's population.
In West Bank-Palestine, cereals occupy the largest cultivated land after fruit trees with total areas of 33,470 hectares, in which wheat contributes the majority of the total field crops in terms of area covered and total production. More preciously, wheat covers an area of 13,270 hectares, in which $99 \%$ of its cultivation is under rain-fed condition with a very low average production of 1,970 Kg per hectare (PCBS, 2013).

In fact, its low productivity might be attributed to a number of reasons including deterioration of the seed cultivars, unsuitable agricultural practices, lack of extension services, and different biotic and abiotic stresses (Basheer-Salimia and Atawne, 2014). Toward this end, drought alone seems to be the most devastating stress since it decreases the overall crop yield more than any other type of plant stress (Ahmad et al., 2015), especially during the last two to three decades, mainly as a direct result of global climate change (Basheer-Salimia and Ward, 2014; Basheer-Salimia and Sayara, 2017).Furthermore, water stress tends to impair plant growth and development and reduces optimal productivity (Farooq et al., 2011; Ahmadizadeh et al., 2013).

Here, detectable climate change has been observed as lower average precipitation rate, more marked changes in the distribution of precipitation from one year to the next, with winter getting shorter and extensive. This situation has produced major fluctuations in wheat yield over the past several years and this variability is expected to get more pronounced in the future. Moreover, wheat is grown in a wide range of geographical and climatical conditions, therefore it is crucial to assess and evaluate the adaptability and suitability of the existing wheat genotypes for each location especially under harsh drought conditions.

\section{MATERIALS AND METHODS}

Plant Materials, Experimental Sites, Design and Plantation: This experiment was carried out using six genotypes of wheat, namely White-Hetia, Yellow-Hetia, Nab-El-Jamal, Um-Ar-Rabee', Anber, and Sury. Seeds were grown at Al-Beera area (southern part of Al-Dahriya city), 
under rain-fed conditions located at the southern highland of West-Bank, Palestine (Figure 1). The targeted area (elevation: $595 \mathrm{~m}$; latitude: $31^{\circ} 26^{\prime} 5^{\prime \prime}$ North; longitude: $34^{\circ} 56^{\prime} 3$ " East) is characterized by low average rainfall and humidity at $390 \mathrm{~mm}$ and $59 \%$, respectively.

The experiment was laid out in a randomized completely block (RCB) design, with three replicates using the net plot size of 333 area (about 1/3 dunum, $22 \mathrm{~m} * 15 \mathrm{~m}$ ) per replicate. To isolate the plots as well as to facilitate the follow-up process (cultural practices, measurements, etc), one meter corridors around all the plots were used. Adoption rate of $5 \mathrm{~kg}$ gram of seeds/wheat genotype/plot (equivalent to $15 \mathrm{~kg} /$ dunum) were manually sown.

Measured and Evaluated Parameters: Maturation and harvesting date were determined when the moisture content of the seeds reaches $15 \%$. Stem length (from the stem base up-to the stem apex); spike with awns length (from the base of the spike to the apex of the awns); awns length (from the base of the awns to the apex of the awns) and tillering (using randomly one square meter frame-quadrate per plot, and then number of fertile tillers for all plant occurring within each quadrate was recorded); were registered. All data was built on a randomly selecting ten representative plants per replicate.

Concerning yield parameters, total yield (grain plus hay), total grain, and total hay production were also recorded in kilograms/plot/genotype, and accordingly calculated per dunum $\left(1000 \mathrm{~m}^{2}\right)$. In addition, weight of 100 seeds per genotype was also measured

Data Analysis: The data were statistically analyzed using one-way analysis of variance (ANOVA) and means were separated using the Tukey's pairwise comparisons at a significance level of $\mathrm{P} \leq 0.05$ using the MINITAB package system.

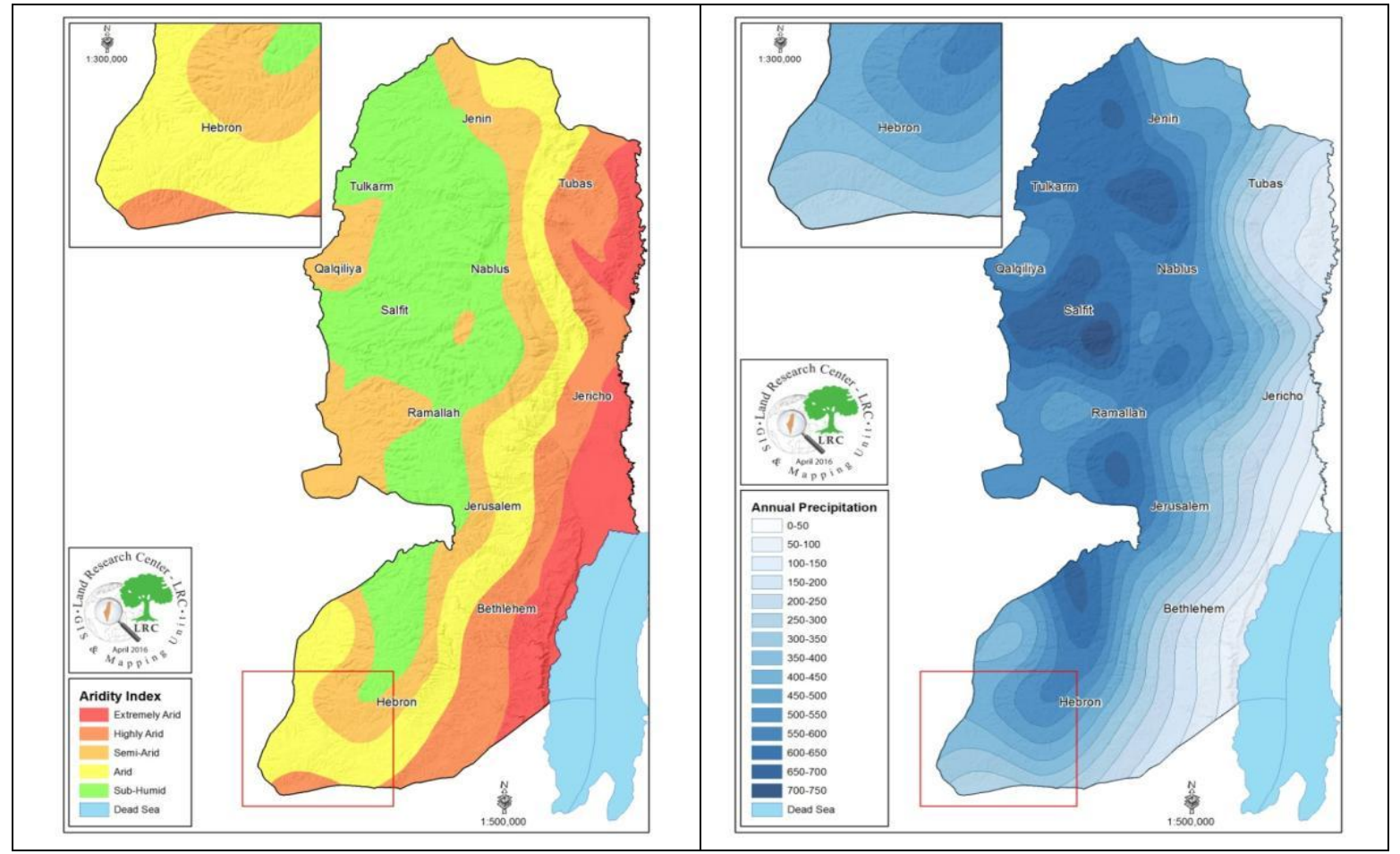

Fig. 1: Maps showed the aridity index of targeted study site (the left) and the average annual precipitation (the wright).

\section{RESULTS}

Morphological parameters: As shown in table (1), significant variation in stem length between the six examined wheat genotypes was observed. Yellow-Hetia genotype presented significant higher stem length, whereas Suri and Anber genotypes exhibited the lowest values, respectively. Meanwhile, the other wheat genotypes revealed almost a moderate stem length.
Concerning the spikes length (spikes and awns) and the awns length, Yellow-Hetia genotype revealed the highest values (20 and $15 \mathrm{~cm}$ respectively), whereas White-Hetia presented the lowest ones. The remaining four genotypes were moderate in these two examined variables.

Furthermore, tiller variable was high in Anber genotype and low in White-Hetia. 
Table.1: Some morphological parameters of different wheat genotypes grown under drought condition. (Mean*土 StDev).

\begin{tabular}{lcccc}
\hline \multicolumn{1}{c}{ Genotype } & Stem Length $(\mathbf{c m})$ & $\begin{array}{c}\text { Spike Length with } \\
\text { awns }(\mathbf{c m})\end{array}$ & $\begin{array}{c}\text { Awns Length } \\
(\mathbf{c m})\end{array}$ & $\begin{array}{c}\text { Tillers } \\
\text { Number }\end{array}$ \\
\hline White-Hetia & $84.21^{\mathrm{b}} \pm 14.03$ & $12.74^{\mathrm{c}} \pm 2.08$ & $10.22^{\mathrm{d}} \pm 1.73$ & $2.53^{\mathrm{c}} \pm 1.35$ \\
Yellow-Hetia & $102.43^{\mathrm{a}} \pm 13.18$ & $19.77^{\mathrm{a}} \pm 2.96$ & $15.33^{\mathrm{a}} \pm 2.27$ & $4.27^{\mathrm{b}} \pm 1.78$ \\
Nab-El-Jamal & $83.46^{\mathrm{b}} \pm 15.75$ & $16.99^{\mathrm{b}} \pm 1.49$ & $12.03^{\mathrm{c}} \pm 1.15$ & $4.80^{\mathrm{b}} \pm 1.63$ \\
Um-El-Rabee' & $72.94^{\mathrm{c}} \pm 10.78$ & $16.90 \mathrm{~b} \pm 0.97$ & $12.29^{\mathrm{bc}} \pm 0.96$ & $5.00^{\mathrm{b}} \pm 2.10$ \\
Anber & $64.92^{\mathrm{d}} \pm 9.26$ & $18.48^{\mathrm{ab}} \pm 2.00$ & $13.43^{\mathrm{b}} \pm 2.59$ & $6.33^{\mathrm{a}} \pm 2.38$ \\
Suri & $61.62^{\mathrm{d}} \pm 6.72$ & $17.75^{\mathrm{b}} \pm 1.34$ & $12.29^{\mathrm{bc}} \pm 1.68$ & $4.53^{\mathrm{b}} \pm 1.20$ \\
$\boldsymbol{P}$ Value & 0.000 & 0.000 & 0.000 & 0.000 \\
\hline
\end{tabular}

*: Means within column using different letters are differ significantly at the $\mathrm{p} \leq 0.05$ level (using one way ANOVA analysis).

Yield parameters: The Yellow-Hetia genotype had the highest significant total yield production (700 kg/dunum), specifically $263 \mathrm{~kg} / \mathrm{dunum}$ as grain and $436 \mathrm{~kg} /$ dunum as hay. However, the remaining genotypes presented almost similar production ranging from 475-488 kg/dunum (Table 2). In contrary, Nab-El-Jamal genotype exhibited the lowest grain production and Um-El-Rabee' genotype revealed the lowest hay production.

Furthermore, significant variations in the weight of 100 seeds of wheat among the six genotypes were observed (Table 2). Indeed, Yellow-Hetia genotype presented the highest average seeds weight, whereas Nab-El-Jamal genotype gave the lowest weight.

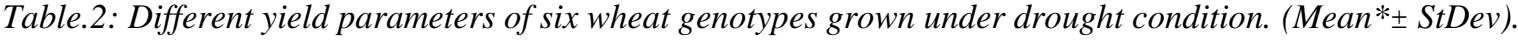

\begin{tabular}{lcccc}
\hline Genotype & $\begin{array}{c}\text { Grain/Seeds } \\
(\text { Kg/dunum) }\end{array}$ & $\begin{array}{c}\text { Hay } \\
(\text { Kg/dunum) }\end{array}$ & $\begin{array}{c}\text { Total Grain+Hay } \\
(\text { Kg/dunum })\end{array}$ & $\begin{array}{c}\text { Weight of 100 } \\
\text { Seeds } \\
(\text { gram })\end{array}$ \\
\hline White-Hetia & $200^{\mathrm{bc}} \pm 4.00$ & $275^{\mathrm{c}} \pm 2.00$ & $475^{\mathrm{b}} \pm 2.00$ & $45^{\mathrm{c}} \pm 2.00$ \\
Yellow-Hetia & $263^{\mathrm{a}} \pm 7.55$ & $436^{\mathrm{a}} \pm 8.27$ & $699^{\mathrm{a}} \pm 11.53$ & $74^{\mathrm{a}} \pm 2.08$ \\
Nab-El-Jamal & $150^{\mathrm{d}} \pm 14.42$ & $334^{\mathrm{b}} \pm 14.24$ & $484^{\mathrm{b}} \pm 27.71$ & $27^{\mathrm{e}} \pm 0.58$ \\
Um-El-Rabee' & $225^{\mathrm{b}} \pm 9.17$ & $250^{\mathrm{d}} \pm 9.54$ & $475^{\mathrm{b}} \pm 7.00$ & $38^{\mathrm{d}} \pm 1.53$ \\
Anber & $200^{\mathrm{bc}} \pm 8.19$ & $288^{\mathrm{c}} \pm 7.00$ & $488^{\mathrm{b}} \pm 8.72$ & $41^{\mathrm{cd}} \pm 1.00$ \\
Suri & $188^{\mathrm{d}} \pm 11.24$ & $298^{\mathrm{c}} \pm 5.29$ & $486^{\mathrm{b}} \pm 12.50$ & $57^{\mathrm{b}} \pm 1.53$ \\
$\boldsymbol{P}$ Value & 0.000 & 0.000 & 0.000 & 0.000 \\
\hline
\end{tabular}

*: Means within column using different letters are differ significantly at the $\mathrm{p} \leq 0.05$ level (using one way ANOVA analysis).

\section{DISCUSSION}

During the last several decades, crops of the Middle-East including Palestine are suffering from low production and productivity in general. In fact, wheat productivity is among the lowest across the region (Basheer-Salimia and Atawnah, 2014). Reason(s) for this catastrophic situation could be either a result of single or multiple factors; however drought seems to be the most important challenge and a major restriction to wheat yield especially in arid and semi-arid regions (Ozturk and Aydin, 2017). Therefore, adaptation of plants to drought stress is a vital and critical issue (Rizhsky et al., 2002).

Many researchers reviewed the factors that can affect plant response to drought stress at morphological, histological, physiological, biochemical, and molecular levels (Nezhadahmadi et al., 2013). Some of these factors might www.ijeab.com include but are not limited to the stage of plant development, duration of stress, and the plant genotype (Chaves et al., 2003). Toward this end, the observed variation among the six examined wheat genotypes (stem length, spike length, awns length, tillers, and different yield parameters) will serve as useful markers for any future wheat breeding program in the region.

Here, the significant higher lengths of stem, spike with awns, and awns presented at Yellow-Hetia genotype could be attributed either to the genetic variations and/or environmental conditions. Since all of the genotypes were examined at the same environmental conditions, we attribute differences to the genetic make-up of the genotypes. Similar results were reported by Shafi and others (1992) who stated that the genetic make-up of any plant affects its qualitative and quantitative characteristics. 
Furthermore, drought was found to reduce the stem length of field crops (Yadavi et al., 2000; Sharpe, 2002), however some stem variations existed that appeared as a result of the genetic make-up of the plants.

A similar variation goes also with the tillering (branching) performance for the different examined wheat genotypes. Simane and others (1993), pointed out that the tillering proliferation is one of the first developmental processes, and it occurs during early growth and depends mainly on the availability of water and nitrogen. However, all examined genotypes were under the same environment, therefore the existing variations are likely genetically related rather than environmentally controlled.

Concerning the yield parameters, Yellow-Hetia genotype was significantly dominant and higher than the other genotypes in terms of total grain, total hay and total yield. The superiority of this genotype could be attributed to the adaptability of such a local genotype and its history that may play a significant role in the formation of yield (Austin et al., 1980; Agoston, 2009), the compliance of this genotype to an thesis under the harsh conditions which therefore increase the fertile-tillers number and accordingly grain-set and yield (Gooding, 2009; Mollasadeghi et al., 2012), and the spikes filling potential and yield.

Furthermore, the highest values of the spike length presented at Yellow-Hetia might explain its higher yield since this feature is considered as the source of assimilates closer to the caryopsis which leads to increases in the accumulated dry matter in the kernels (Thorne, 1974). Furthermore, spikes commonly stay green and functional for a longer time together with the awns (Sharma et al., 2003), thereby resulting in higher yield.

Moreover, awns found to have a direct vascular linkage with the spike because head photosynthesis tends to be much higher when awns are well developed (Weyhrich et al., 1995). Moreover, awns have been shown to be advantageous during drought stress in the driest of areas (Motzo and Giunta, 2002).

Generally, the grain weight is considered to be influenced by the environmental conditions as well as the agronomic inputs throughout different growth stages of the crop (Edwards, 2010). In fact, drought and limited water availability are the main factors limiting crop production (Seghatoleslami et al., 2008). Here, it is obvious that Yellow-Hetia is promising genotypes for future breeding programs since it presents significantly higher yield compared with the other 5 wheat genotypes when examined under the same climatic conditions. This result is in agreement with Jaleel and others (2007), who stated that almost all plants are tolerant to drought stress but the extent www.ijeab.com of this varies from species to species and even within species.

\section{ACKNOWLEDGMENT}

The authors would like to express their gratitude to the Italian Agency for Development and Cooperation for funding this research within the framework of the project “AID 010139/CRIC/TOC”.

\section{REFERENCES}

[1] Agoston, T. (2009). Effect of the crop year on the agronomical traits of wheat varieties. $\mathrm{PhD}$ thesis, University of Debrecen.

[2] Ahmad, Y., S. El-Sarafy, and E. Lutz (eds) (1989). Environmental Accounting and Sustainable Development. Washington, D.C. World Bank. (World Bank Symposia Series).

[3] Ahmad, I., I. Khaliq N. Mahmood and N. Khan (2015). Morphological and physiological criteria for drought tolerance at seedling stage in wheat. The Journal of Animal \& Plant Sciences. 25(4): 10411048.

[4] Ahmadizadeh, M. (2013). Physiological and agromorphological response to drought stress. Middle-East J. Sci. Res. 13: 998-1009.

[5] Austine, R.B. (1980). Physiological limitation to cereal yields and ways of reducing them by breeding. In: Opportunities for increasing crop yields. Pitman Pub., London.

[6] Basheer-Salimia R. and S. Atawnah (2014). Morphological features, yield components and genetic relatedness of some wheat genotypes grown in Palestine. World Journal of Agricultural Research. 2(1): 12-21.

[7] Basheer-Salimia, R. and T. Sayara (2017). Using Stable Isotope $(\delta 13 \mathrm{C})$ and $\mathrm{C} / \mathrm{N}$ ratio to study the effects of Climate Change on Olive trees. Arab American University Journal. 3 (1): 22-39.

[8] Basheer-Salimia, R. and J. Ward (2014). Climate change and its effects on olive tree physiology in Palestine. Review of Research Journal. 3(7): 1-7.

[9] Chaves M. M., J. P. Maroco, and J. S. Pereira (2003). Understanding plant responses to drought-from genes to the whole plant," Functional Plant Biology, vol. 30, no. 3, pp. 239-264.

[10] Edwards, M (2010). Morphological features of wheat grain and genotype affecting flour yield, $\mathrm{PhD}$ thesis, Southern Cross University, Lismore, NSW. 
[11]FAO (2016). Publication of the Food and Agricultural Organization of the United Nations, World Food Program, Cereal supply and demand, Rome, Italy.

[12]FAO (2017). Publication of the Food and Agricultural Organization of the United Nations, World Food Program, Cereal supply and demand, Rome, Italy.

[13] Farooq, J., I. Khaliq, M. A. Ali, M. Khashif, A. Rehman, M. Naveed, Q. Ali, W. Nazeer and A. Farooq (2011). Inheritance pattern of yield attributes in spring wheat at grain filling stage under different temperature regimes. Aust. J. Crop Sci. 5(13): 1745-1753.

[14] Gooding, M.J. (2009). The wheat crop. In: Khan K, Shewry P. R (eds) Wheat: Chemistry and Technology, 4th ed. AACC International, Minnesota. 35-70.

[15] Jaleel, C., P. Manivannan, A. Kishorekumar, B. Sankar, R. Gopi, R. Somasundaram, and R. Panneerselvam (2007). Alterations in osmoregulation, antioxidant enzymes and indole alkaloid levels in Catharanthusroseus exposed to water deficit. Colloids Surf. B: Bio-inter-faces. 59: 150-157.

[16] Mollasadeghi, V., S. Elyasi, and B. Mirzamasoumzadeh (2012). Genetic variation of 12 bread wheat genotypes based on number of phonological and morphological traits. Ann. Biol. Res. 3: 4734-4740.

[17] Motzo, R. and F.Giunta (2002). Awnedness affects grain yield and kernel weight in near-isogenic lines of durum wheat. Australian Journal of Agricultural Research. 53: 1285-1293.

[18] Nezhadahmadi, A., Z. Prodhan, and G. Faruq (2013). Drought Tolerance in Wheat. The Scientific World Journal.2013.

[19] ÖZTÜRK, A. and M.AYDIN (2017). Physiological characterization of Turkish bread wheat genotypes for resistance to late drought stress. Turk J Agric For. 41: 414-440.

[20]PCBS (2013). Agricultural Statistics. Palestinian Central Bureau of Statistics, Ramallah, Palestine.
[21] Rizhsky, L., H. Liang, and R. Mittler (2002). The combined effect of drought stress and heat shock on gene expression in tobacco. Plant Physiology. 130(3): 1143-1151.

[22] Seghatoleslami, M. J., M. Kafi, E. Majidi (2008). Effect of drought stress at different growth stages on yield and water use efficiency of five proso millet (Panicum miliaceum L.) genotypes. Pak J Bot 40: 1427-1432.

[23] Shafi, M., S. Khan and M. Nazir (1992). Yield and yield components of wheat in relation to different phosphorus and radiation levels. Sarhad. J. Agril. 8: 15 .

[24] Sharma S.N., R.S. Sain, and R.K. Sharma (2003). Genetics of spike length in durum wheat. Euphytica. 130:155-161.

[25] Sharpe, R.E. (2002). Interaction with ethylene: changing views on the role of abscisic acid in root and shoot growth responses to water stress. Plan Cell and Environment. 25: 211-222.

[26] Simane, B., P.C. Struik, M.M. Nachit, J.M. Peacock (1993). Ontogenetic analysis of yields and yields components and yield stability of durum wheat in water-limited environments. Euphytica. 71: 211-219.

[27] Thorne, G.N. (1974). Physiology of grain yield of wheat and barley, Rothamsted Experimental Station, Report for 1973, part 2, pp 5-25.

[28] Weyhrich, R.A., B.F. Carver, B.C. Martin (1995). Photosynthesis and water-use efficiency of awned and awnletted near-isogenic lines of hard red winter wheat. Crop Sci. 35:172-176

[29] Yadavi, A., A. Modaress-Sanavi, and R.Zarghami (2000). The effects of drought stress on oats species in Germination Step. Articles summary in 6th session of agriculture and plants improvement congress, Iran, Mazandaran University. 235-236. 